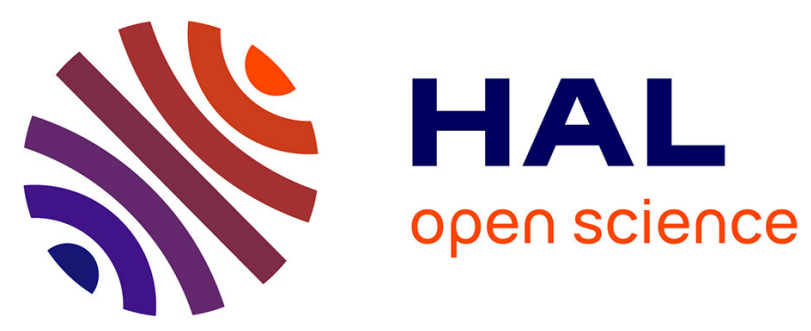

\title{
Building Business Resilience with Social Media in B2B Environments: The Emergence of Responsive Customer Relationship Management Processes on Twitter
}

\author{
Jyotirmoyee Bhattacharjya, Adrian B. Ellison
}

\section{- To cite this version:}

Jyotirmoyee Bhattacharjya, Adrian B. Ellison. Building Business Resilience with Social Media in B2B Environments: The Emergence of Responsive Customer Relationship Management Processes on Twitter. 16th Working Conference on Virtual Enterprises (PROVE), Oct 2015, Albi, France. pp.170177, 10.1007/978-3-319-24141-8_15 . hal-01437883

\section{HAL Id: hal-01437883 \\ https://hal.inria.fr/hal-01437883}

Submitted on 17 Jan 2017

HAL is a multi-disciplinary open access archive for the deposit and dissemination of scientific research documents, whether they are published or not. The documents may come from teaching and research institutions in France or abroad, or from public or private research centers.
L'archive ouverte pluridisciplinaire HAL, est destinée au dépôt et à la diffusion de documents scientifiques de niveau recherche, publiés ou non, émanant des établissements d'enseignement et de recherche français ou étrangers, des laboratoires publics ou privés. 


\title{
Building Business Resilience with Social Media in B2B Environments: The Emergence of Responsive Customer Relationship Management Processes on Twitter
}

\author{
Jyotirmoyee Bhattacharjya $^{1}$, Adrian B.Ellison ${ }^{1}$, \\ ${ }^{1}$ Institute of Transport and Logistics Studies, The University of Sydney, NSW 2006, \\ Australia \\ \{jyotirmoyee.bhattacharjya, adrian.ellison\}@ sydney.edu.au
}

\begin{abstract}
Companies operating in the business-to-consumer (B2C) space have been increasingly using the social media platform, Twitter, to conduct customer relationship management activities. Similar practices are also gradually emerging in business-to-business (B2B) environments. However, B2B service providers are yet to incorporate social media into their overall business strategy to the extent that this has become common practice amongst $\mathrm{B} 2 \mathrm{C}$ companies. Engaging with customers over social media poses both risks and opportunities for companies. This paper examines the customer relationship management activities of a B2B service provider, Shopify, to identify opportunities for improving brand perception and business resilience.
\end{abstract}

Keywords: business-to-business services, social media, Twitter, customer relationship management, brand resilience, Shopify

\section{Introduction}

In recent years, there has been a rapid growth in the adoption of social media platforms for conducting B2C interactions. This is largely because companies around the world have recognized the need to build and protect their brands in the virtual environments in which consumers express their opinions and engage with their peer groups. The microblogging site, Twitter, has become the social media platform most widely adopted by Fortune 500 companies [2]. Previous research undertaken by the authors [1] has demonstrated that these companies are not only using Twitter for promotional purposes but for the provision of customer service as well. However, companies operating in the $\mathrm{B} 2 \mathrm{~B}$ space have not as yet adopted social media as extensively as their B2C counterparts and there is a lack of understanding amongst these firms regarding how social media could help the resilience of their brands [3][4].

Nevertheless, some B2B service providers are beginning to take a strategic approach to their social media. This paper presents findings in relation to the customer relationship management (CRM) activities of a B2B company. The data presented here is part of a larger ongoing project initiated in December 2014 which 
has now collected over 5 million tweets (microblogs) from B2B and B2C companies. The uniqueness of the project lies in the fact that, unlike previous studies, it is designed to extract entire conversations rather than just tweets on a large scale.

\section{Background and Literature Review}

Social CRM or CRM 2.0, is a term coined by president of The 56 Group and leading CRM thinker, Paul Greenberg describes "a philosophy and a business strategy, supported by a technology platform, business rules, workflow, processes and social characteristics, designed to engage the customer in a collaborative conversation in order to provide mutually beneficial value in a trusted and transparent business environment. It's the company's response to the customer's ownership of the conversation" ([5],[6]). This definition highlights the need for a shift in focus from customer management to customer engagement in an era where the customer is in increasing control of the narrative due to the proliferation of social media platforms.

The combination of rapid technological changes and regulatory and geopolitical upheavals over the past decade have led companies to recognize the need for resilient strategies that allow them to adapt their business models as well as their marketing approaches as their local or global contexts evolve ([17], [18]). As an increasing number consumers around the world build their presence on social media platforms, companies have recognized that news travels fast through social networking sites and complacency is not an option in ensuring the resilience of their brands [7]. Dell, for instance, has a Social Media Listening Command Center to monitor customer conversations about its brand on social media platforms [8]. Online retailer Amazon has also been at the forefront of customer engagement via social media and attempts to address customer complaints through its Twitter based channel as quickly as possible [1]. PepsiCo and Gap are also amongst other big brand owners and retailers engaging customers in conversations about their products in order to keep abreast of brand perceptions and ensure brand resilience ([9],[10]).

However, as previously stated, while B2C companies have begun using social media sites to their advantage, B2B companies have been slow on the uptake ([3],[4]). The business software industry is the leading B2B sector in terms of social media activity, with Intel, Oracle and IBM being key players in the sector. The medical and pharmaceutical sector, with leaders such as Pfizer, Merck and GlaxoSmithKlein is the second most active sector. Other sectors, such as the B2B logistics sector are much less active on social media with only a few companies in each sector making a noticeable effort. For instance, the container shipping company, Maersk, is one of the few companies in the $\mathrm{B} 2 \mathrm{~B}$ logistics space that has been recognized for building its presence across social media channels [11]. It has over 34,000 followers on Twitter and over 2.2 million likes on Facebook. However, while B2B companies are beginning to building their presence on social media, few are using these platforms to provide customer service and build closer ties with customers. This is in significant contrast to the growing number of $\mathrm{B} 2 \mathrm{C}$ companies who have dedicated customer service accounts on Twitter and are taking a proactive approach to engaging in conversations with customers to manage satisfaction and brand perception. 


\section{Research Method}

Twitter allows users to post microblogs or tweets which are limited to 140 characters in length. A user's timeline consists of tweets from accounts the user has chosen to follow on Twitter. These tweets can be accompanied by links, photos and videos and may be retweeted or replied to by the user. Tweets, retweets and responses are generally visible to the general public unless a direct message (DM) is sent by one user to another. The public nature of most of these interactions has led a diverse range of companies to monitor discussions about themselves and reach out to customers using this platform. The limitations posed by the Twitter application programming interface (API) on the extraction of tweets along a user's timeline along with a lack of tweet extraction tools with appropriate capabilities has led to most research till date being focused on the sentiment analysis of individual tweets ([12],[13]) rather than the conversations between interacting parties on this platform. For this research, a custom application package was developed to extract tweets from the timelines of companies of interest along with the conversations associated with these tweets. Each tweet on Twitter is allocated a unique identification number. The package developed for this research allows the tweets to be written to a MySQL database allocates identification numbers for the conversations thus allowing the subsequent analysis of not just tweets but conversations as well. Since December 2014, the package has been used to collect over 5 million tweets from companies and their customers. The data collection methodology is discussed in more detail by the authors in another paper [16]. The conversations are subsequently extracted from Twitter and uploaded to the text mining tool for coding and analysis.

\section{Findings}

One company that has both undergone business model transformation and adapted its marketing strategies to the proliferation of social media is the billion dollar Canadian ecommerce solution provider Shopify. The company started out as an online store for selling snowboards. It later developed its own e-commerce solution and developed into an e-commerce platform because of interest from other online retailers. As an ecommerce company, it allows businesses to set up online stores organize products, accept payments, and track orders. Its ecosystem comprises of small businesses, developers and end consumers. Although, its accounts on Twitter are oriented towards business customers, the platform allows it to get exposure to end consumers as well, thus giving it wider brand recognition. Its site received about 15-20 million visits per month in the last six months [15]. Around $10.5 \%$ of the visits in the last three months have been from Twitter. It not only encourages customers to use the power of social media to create greater awareness of their offerings but has also been making a concerted effort to build its own presence on social media. As outlined in Table 1, it maintains a number of accounts on Twitter. 
Table 1. Shopify's accounts on Twitter.

\begin{tabular}{|c|c|c|c|}
\hline Account & Purpose & Tweets & Followers \\
\hline @ Shopify & $\begin{array}{l}\text { Main account which also addresses } \\
\text { customer service queries }\end{array}$ & 16,900 & 157,000 \\
\hline @ ShopifySupport & Dedicated customer service account & 2,051 & 3,276 \\
\hline @ ShopifyPicks & $\begin{array}{l}\text { Product stream curated from over } \\
160,000 \text { Shopify powered stores } \\
\text { around the world }\end{array}$ & 4,542 & 28,100 \\
\hline @ ShopifyDevs & $\begin{array}{l}\text { News for developers about the } \\
\text { Shopify API }\end{array}$ & 687 & 3897 \\
\hline @ShopifyMasters & $\begin{array}{l}\text { Advice on growing store traffic and } \\
\text { sales based on success stories of } \\
\text { Shopify customers }\end{array}$ & 3552 & 5697 \\
\hline @ ShopifyPartners & $\begin{array}{l}\text { Account for the Shopify Partners } \\
\text { Program }\end{array}$ & 4602 & 7165 \\
\hline
\end{tabular}

By way of comparison, Amazon, which has been on Twitter since February 2009, has over 13,400 tweets on its main account and over 1.84 million followers. Its customer service account, operational since October 2009, has over 242,000 tweets and 24,000 followers. The differences in the numbers are indicators of the different levels of activity on Twitter in B2C and B2B contexts but both companies appear to take their presence on Twitter seriously as suggested by their verified accounts on Twitter. A Twitter verified account has a blue verified badge associated with the account [14]. Twitter does not accept verification requests but prioritizes highly sought users as part of their ongoing verification process.

\subsection{Customer Service Interactions}

As shown in Table 2, customers generally post tweets to make Shopify aware of problems with their system that are interrupting or slowing down business processes. Such tweets may also be accompanied by photos that communicate the problem. Monitoring the Twitter accounts allows Shopify to respond quickly on a public platform, thus allowing it to demonstrate its responsiveness to a wider customer base. The company also uses its Twitter accounts to provide information or direct customers to websites where the information may be available.

Table 2. A conversation with a customer following a system problem.

\begin{tabular}{lll}
\hline User & Tweet & UTC Date, Time \\
\hline @ notrab & $\begin{array}{l}\text { Just spent 30 minutes editing a file with @ Shopify } \\
\text { templates and then it errors on save. Doh }\end{array}$ & $5: 22$ am, Feb 20, 2015 \\
@ Shopify & $\begin{array}{l}\text { @ notrab Oh no! So sorry about that Jamie. We are } \\
\text { working on getting everything back up as soon as } \\
\text { possible! }\end{array}$ & 5:35 am, Feb 20, 2015 \\
@ notrab & @hopify That's ok! :) & $5: 35$ am, Feb 20, 2015 \\
\hline
\end{tabular}

In the previous example Shopify was able to inform the customer that it was working on the problem. In other instances the platform allows the company to build 
goodwill by providing information that resolves a perceived problem (Table 3).

Table 3. A conversation with a customer following a system problem.

\begin{tabular}{|c|c|c|}
\hline User & Tweet & UTC Date, Time \\
\hline @Misc_Goods_Co & $\begin{array}{l}\text { @ Shopify y?! } \\
\text { message] }\end{array}$ & $\begin{array}{l}\text { 7:27 am, Dec } \\
19,2014\end{array}$ \\
\hline @Misc_Goods_Co & $\begin{array}{l}\text { @Shopify @ ShopifySupport I'm very } \\
\text { frustrated about this new POS fee. I only need } \\
\text { to use POS a few times a year. }\end{array}$ & $\begin{array}{l}\text { 8:43 am, Dec } \\
19,2014\end{array}$ \\
\hline @Misc_Goods_Co & $\begin{array}{l}\text { @Shopify @ShopifySupport I've been sitting } \\
\text { here at my last minute pop up like a bozo } \\
\text { trying to figure out why it's not working. }\end{array}$ & $\begin{array}{l}\text { 8:44 am, Dec } \\
19,2014\end{array}$ \\
\hline @Misc_Goods_Co & $\begin{array}{l}@ \text { Shopify @ Shopifysupport very bad taste in } \\
\text { my mouth right now }\end{array}$ & $\begin{array}{l}8: 45 \text { am, Dec } \\
19,2014\end{array}$ \\
\hline @Shopify & $\begin{array}{l}\text { @Misc_Goods_Co Thank you for the } \\
\text { feedback and very sorry for any frustration. It } \\
\text { is free to process on Shopify Mobile. }\end{array}$ & $\begin{array}{l}8: 51 \text { am, Dec } \\
19,2014\end{array}$ \\
\hline @Misc_Goods_Co & $\begin{array}{l}\text { @Shopify well that's cool. went from } \\
\text { frustrated to pretty chill. wasn't aware of that } \\
\text { change }\end{array}$ & $\begin{array}{l}\text { 9:00 am, Dec } \\
19,2014\end{array}$ \\
\hline @Shopify & $\begin{array}{l}\text { @Misc_Goods_Co Thanks for letting us } \\
\text { know. We are happy to help with other } \\
\text { questions. }\end{array}$ & $\begin{array}{l}\text { 9:49 am, Dec } \\
19,2014\end{array}$ \\
\hline
\end{tabular}

Like companies in the B2C space [1], Shopify uses Twitter in conjunction with other traditional channels for providing customer service such as email and phone. However, there are some risks associated with a social media presence. Customers may contact the company via Twitter if satisfactory customer service is not received promptly via other less public media but it may not be possible for the company to provide a resolution via the platform (e.g., Table 4). Thus while the conversation may suggest that the company hasn't been able to resolve problems promptly, someone (e.g., a potential customer) visiting its Twitter account may be left wondering whether the query was resolved to the customer's satisfaction. As with B2C companies, customers are found to rarely return to thank a company via the Twitter platform if the query is resolved via a more private channel.

Table 4. A conversation with a customer following a system problem that was originally communicated through a traditional channel.

\begin{tabular}{|c|c|c|}
\hline User & Tweet & UTC Date, Time \\
\hline @ gooderdle & $\begin{array}{l}\text { @ ShopifySupport - as an early supporter of } \\
\text { Shopify, we'd like to upgrade but keep our } \\
\text { grandfathered "No transaction fee"... cc @ } \text { Shopify }\end{array}$ & $8: 15$ am, Jan 16,2015 \\
\hline @ Shopify & $\begin{array}{l}\text { @ gooderdle We'd be happy to look into that. Can } \\
\text { you please contact our billing team - } \\
\text { billing[at]shopify[dot]com.. }\end{array}$ & 8:52 am, Jan 16, 2015 \\
\hline @Shopify & What is your open ticket number? & 8:54 am, Jan 16, 2015 \\
\hline @ gooderdle & $\begin{array}{l}\text { No open ticket number - been going back and forth } \\
\text { over email and phone for a week with a "Sales } \\
\text { Lead" }\end{array}$ & 8:58 am, Jan 16, 2015 \\
\hline
\end{tabular}


Even if a conversation starts on Twitter, Shopify may still divert the query to email (Table 5). Unlike B2C companies, Shopify makes very limited use of Twitter's direct messaging (DM) service to address problems that cannot be resolved in public.

Table 5. A conversation that starts on Twitter but has to be diverted to a different channel.

\begin{tabular}{|c|c|c|}
\hline User & Tweet & $\begin{array}{l}\text { UTC Date, } \\
\text { Time }\end{array}$ \\
\hline @ Schappi & $\begin{array}{l}\text { @ Shopify heads up that I'm getting multiple reports } \\
\text { of shipping methods not loading at checkout }\end{array}$ & $\begin{array}{l}8: 40 \mathrm{pm}, \text { Dec } \\
10,2014\end{array}$ \\
\hline @Shopify & $\begin{array}{l}\text { @Schappi Apologies for the delay. Are you still } \\
\text { experiencing issues? }\end{array}$ & $\begin{array}{l}\text { 6:56 am, Dec } \\
11,2014\end{array}$ \\
\hline @ Schappi & $\begin{array}{l}\text { @Shopify yup we are still experiencing issues... } 3 \\
\text { people today complained. Just migrated all stores to } \\
\text { responsive to see if that fixes it. }\end{array}$ & $\begin{array}{l}8: 04 \mathrm{pm}, \mathrm{Dec} \\
11,2014\end{array}$ \\
\hline @ Shopify & $\begin{array}{l}\text { @ Schappi Thanks for getting back to us. Please email } \\
\text { support[at]shopify[dot]com with more info and } \\
\text { respond with the ticket number. }\end{array}$ & $\begin{array}{l}8: 34 \text { am, Dec } \\
12,2014\end{array}$ \\
\hline
\end{tabular}

\subsection{Collaborative Approach to Marketing}

The company appears to recognize the fact that the resilience of its ecosystem which comprises of a large number of small businesses is essential for its own resilience. It takes a collaborative approach to its marketing activities and uses its @ShopifyPicks account on Twitter to highlight products sold by companies that use Shopify as their ecommerce solution (Table 1). This allows small companies with modest resources, such as Stitch \& Locke, to focus on their core businesses and provide customers with links to Shopify's main Twitter account instead of maintaining their own. There is both a downside and an upside to this approach. End consumers may approach Shopify directly with queries regarding products and services provided by Shopify's customers. The upside is that if it is handled well, this may create a positive impression of its brand beyond the B2B environment in which it operates (Table 6). In the conversation below, the customer adds a hashtag \#brandPlus to show his appreciation for the prompt response. Hashtags are searchable on Twitter and allow users to easily find comments on particular topics.

Table 6. Shopify's exposure to the B2C interface via Twitter.

\begin{tabular}{|c|c|c|}
\hline User & Tweet & $\begin{array}{l}\text { UTC Date, } \\
\text { Time }\end{array}$ \\
\hline @Marcus & @ Shopify Hi there. I bought from stich and locke. My & 9:13 am, Dec \\
\hline Kourie & $\begin{array}{l}\text { delivery address needs to be changed though, how do I } \\
\text { go about this? }\end{array}$ & 11,2014 \\
\hline @ Shopify & $\begin{array}{l}\text { @MarcusKourie Please try contacting the store } \\
\text { through their about us page or the original order } \\
\text { notification. }\end{array}$ & $\begin{array}{l}9: 24 \text { am, Dec } \\
11,2014\end{array}$ \\
\hline $\begin{array}{l}\text { @Marcus } \\
\text { Kourie }\end{array}$ & $\begin{array}{l}\text { @Shopify Thank you! Appreciate you prompt } \\
\text { response. \#brandPlus }\end{array}$ & $\begin{array}{l}3: 19 \text { am, Dec } \\
12,2014\end{array}$ \\
\hline
\end{tabular}


The company also engages with developers via Twitter in two ways. On the one hand it keeps developers informed about changes to its API using the @ ShopifyDevs and @ShopifyPartners accounts so they can continue to support and build solutions for their customers. On the other hand it encourages them to earn money by developing apps, designing themes or referring clients to the Shopify platform. The @ ShopifyPartners account helps to highlight successful activities of partners and create a community atmosphere.

\section{Discussions}

In the B2B environment there continues to be lower uptake of social media platforms for customer service and promotional activities that might help these companies build wider brand recognition and resilience. Those B2B companies who are present on social media are largely engaged in a one-way communication where the provision of news and updates seems to be the only purpose for maintaining the Twitter accounts. However, even though their levels of activity may be noticeably lower than those of the more active B2C companies on Twitter (e.g. Amazon), a small number of B2B companies such as Shopify are beginning to take a more strategic approach to this platform. In Shopify's case, this involves structuring its engagement with the members of its ecosystem using a number of dedicated accounts for specific purposes. Adequate resourcing of a social media strategy is essential for its success. For instance, Shopify was generally found to respond to customer and developer queries within the hour. The company's two-way engagement with small business customers, developers and consumers and its attempts to approach benefits to its ecosystem holistically through its accounts on Twitter makes it an exemplar amongst B2B companies. The ongoing longitudinal data collection project will examine the emerging trends in the practices of $\mathrm{B} 2 \mathrm{~B}$ companies around the world and provide further insights into how these practices can help to nurture resilient business ecosystems.

\section{References}

1. Bhattacharjya, J., Tripathi, S., Ellison A.B., and Kitratporn, N.: Creation Using Social Media in a Virtual Business Model: How Amazon Approaches Customer Service on Twitter. In: 24th International Business Information Management Association Conference on Crafting Global Competitive Economies: 2020 Vision Strategic Planning \& Smart Implementation, pp. 2208--2215. Milan, Italy (2014)

2. Culnan, M., McHugh, P.J., Zubillaga, J.I.: How large U.S. companies can use Twitter and other social to gain business value. MIS Quarterly Executive, vol. 9, pp. 243--259 (2010)

3. Michaelidou, N., Siamagka, N.T., Christodoulides, G.: Usage, barriers and measurement of social media marketing: An exploratory investigation of small and medium brands. Industrial Marketing Management, vol. 40, pp. 1153--1159 (2011) 
4. Swani, K., Brown, B.P., Milne, G.R.: Should tweets differ for B2B and B2C? An analysis of Fortune 500 companies' Twitter communications. Industrial Marketing Management, vol. 9, pp. 243--259 (2014)

5. Greenberg, P.: CRM at the speed of light: social CRM strategies, tools, and techniques for engaging your customers. McGraw-Hill, New York (2009)

6. PGreenblog, http://the56group.typepad.com/pgreenblog/2009/07/time-to-put-a-stake-in-theground-on-social-crm.html (2009)

7. Copulsky, J., Fritz, A., White, M.: Protecting your brand from saboteurs in a high-speed world. Deloitte Review, iss. 9, pp. 88--101(2011)

8. Menchacha, L.: Dell's next step: The Social Media Command Center, http://en.community.dell.com/dell-blogs/Direct2Dell/b/direct2dell/archive/2010/12/08/dells-next-step-the-social-media-listening-command-center (2010)

9. Bauerlein, V.: Gatorade's mission: sell more drinks. The Wall Street Journal, http://www.wsj.com/articles/SB10001424052748703466704575489673244784924 (2010)

10. Morales, G., Nemer, N., Bhattacharjya, J.: The Impact of Twitter on Customer Relationship Management within Mexican Value Chains. In: 1st International Conference on Value Chain Management - Modelling Value, Pre-Proceedings Volume 2, pp. 219--239. Shaker Verlag, Aachen, Germany (2011)

11. Maersk Social, http://www.maersk.com/en/social

12. Jansen, B.J., Zhang, M., Sobel, K., Chowdhury, A.: Twitter power: Tweets as electronic word of mouth. Journal of the American Society for Information Science and Technology, vol. 60, pp. 2169--2188, (2009)

13. Liau, B.Y., Tan.P.P.: Gaining customer knowledge in low cost airlines through text mining. Industrial Management and Data Systems, vol. 114, pp. 1344--1359 (2014)

14. Twitter, https://support.twitter.com/articles/119135-faqs-about-verified-accounts\#

15. Similarweb, http://www.similarweb.com/website/shopify.com?utm_source=checkpagerank. net\&utm_medium=SourcesWidget\&utm_campaign=mb_SourcesWidget_checkpagerank.net

16. Bhattacharjya, J., Ellison, A.B., Tripathi, S.: An exploration of logistics related customer service provision on Twitter: The case of e-tailers. International Journal of Physical Distribution \& Logistics Management, accepted (2015)

17. Hamel, G., Välikangas, L.: The quest for resilience. Harvard Business Review, vol. 81, pp. 52--63 (2003)

18. Day, G.S.: Closing the Marketing Capabilities Gap. Journal of Marketing, vol. 75, pp. 183-195 (2011) 